\title{
Article \\ Cross-Validation of Predictive Equation for Cardiorespiratory Fitness by Modified Shuttle Walk Test in Adults with Schizophrenia: A Secondary Analysis of the CORTEX-SP Study
}

\author{
Mikel Tous-Espelosin ${ }^{1,2}$, Sonia Ruiz de Azua ${ }^{3}$, Nagore Iriarte-Yoller ${ }^{4}$, Pedro M. Sanchez ${ }^{4,5}$, \\ Edorta Elizagarate ${ }^{4}$, Agurne Sampedro ${ }^{6}$ and Sara Maldonado-Martín ${ }^{1,2, *}$ (i)
}

check for updates

Citation: Tous-Espelosin, M.; Ruiz de Azua, S.; Iriarte-Yoller, N.; Sanchez, P.M.; Elizagarate, E.; Sampedro, A.; Maldonado-Martín, S. Cross-Validation of Predictive Equation for Cardiorespiratory Fitness by Modified Shuttle Walk Test in Adults with Schizophrenia: A Secondary Analysis of the CORTEX-SP Study. Int. J. Environ Res. Public Health 2021, 18, 11390. https://doi.org/10.3390/ ijerph182111390

\section{Academic Editors:}

Georgina Stebbings, Shane Heffernan Kirsty Hicks and Antonis Elia

Received: 29 September 2021

Accepted: 27 October 2021

Published: 29 October 2021

Publisher's Note: MDPI stays neutral with regard to jurisdictional claims in published maps and institutional affiliations.

Copyright: (c) 2021 by the authors. Licensee MDPI, Basel, Switzerland. This article is an open access article distributed under the terms and conditions of the Creative Commons Attribution (CC BY) license (https:// creativecommons.org/licenses/by/ $4.0 /)$
1 GIzartea, Kirola eta Ariketa Fisikoa Ikerkuntza Taldea (GIKAFIT), Society, Sports and Physical Exercise Research Group, Department of Physical Education and Sport, Faculty of Education and Sport-Physical Activity and Sport Sciences Section, University of the Basque Country (UPV/EHU), 01007 Vitoria-Gasteiz, Spain; mikel.tous@ehu.eus

2 Physical Activity, Exercise and Health Group, Bioaraba Health Research Institute, 01009 Vitoria-Gasteiz, Spain

3 Cibersam, Department of Neuroscience, University of the Basque Country (UPV/EHU), 48940 Leioa, Spain; sonia.ruizdeazua@ehu.eus

4 Refractory Psychosis Unit, Psychiatric Hospital of Alava, 01007 Vitoria-Gasteiz, Spain; nagore.iriarteyoller@osakidetza.eus (N.I.-Y.); pedromanuel.sanchezgomez@osakidetza.eus (P.M.S.); eduardojose.elizagaratezabala@osakidetza.eus (E.E.)

5 Faculty of Medicine, University of Deusto, 48007 Bilbao, Spain

6 Department of Psychology, Faculty of Health Sciences, University of Deusto, 48007 Bilbao, Spain; a.sampedro@deusto.es

* Correspondence: sara.maldonado@ehu.eus; Tel.: +34-945013534; Fax: +34-945013501

Abstract: Cardiorespiratory fitness (CRF) can be direct or estimated from different field tests. The Modified Shuttle Walk Test (MSWT) is suitable for all levels of function, allowing a peak response to be elicited. Therefore, we aimed (1) to validate the equation presented in the original study by Singh et al. for evaluating the relationship between MSWT with peak oxygen uptake $\left(\mathrm{VO}_{2 \text { peak }}\right)$ in adults with schizophrenia (SZ), (2) to develop a new equation for the MSWT to predict $\mathrm{VO}_{2 \text { peak }}$, and (3) to validate the new equation. Participants $(\mathrm{N}=144,41.3 \pm 10.2$ years old) with SZ performed a direct measurement of $\mathrm{VO}_{2 \text { peak }}$ through a cardiopulmonary exercise test and the MSWT. A new equation incorporating resting heart rate, body mass index, and distance from MSWT $\left(\mathrm{R}^{2}=0.617\right.$; adjusted $\left.\mathrm{R}^{2}=0.60 ; p<0.001\right)$ performs better than the Singh et al. equation $\left(\mathrm{R}^{2}=0.57\right.$; adjusted $\mathrm{R}^{2}=0.57$; $p<0.001)$ to estimate $\mathrm{VO}_{2 \text { peak }}$ for the studied population. The posteriori cross-validation method confirmed the model's stability $\left(R^{2}=0.617\right.$ vs. 0.626$)$. The findings of the current study support the validity of the new regression equation incorporating resting heart rate, body mass index, and distance from MSWT to predict $\mathrm{VO}_{2 \text { peak }}$ for assessment of CRF in people with SZ.

Keywords: assessment; equation for estimation; field test; peak oxygen uptake; validation

\section{Introduction}

Schizophrenia (SZ) is a chronic severe mental illness with an important bearing on the presence of cardiovascular risk (CVR) factors due to an unhealthy lifestyle, including lack of physical activity [1], smoking, substance abuse, and poor diet [2], along with adverse effects of medications [3] and social and economic factors [4].

Hence, according to different clinical guidelines, the control and assessment of CVR in SZ patients are recommended [5-7]. In this regard, a previous study has shown that people with SZ have a moderate CVR compared to a low CVR in healthy controls [8]. Therefore, any physical exercise program offered to SZ patients as a non-pharmacological co-adjuvant intervention should include a previous assessment. 
Besides the traditional parameters, cardiorespiratory fitness (CRF, i.e., the capacity of the cardiovascular and pulmonary systems to meet the oxygen demands of skeletal muscle during physical work) is considered a vital sign and has emerged as a modifiable risk factor to attenuate the risk of developing non-communicable diseases $[9,10]$. Thus, a poor CRF level has been associated with a higher increased mortality risk, independently of other clinical risk factors [9].

The measurement of CRF can be direct, expressed as maximum or peak oxygen consumption $\left(\mathrm{VO}_{2 \max }\right.$ or $\left.\mathrm{VO}_{2 \text { peak }}\right)$, or estimated from different ergometer or field tests [11]. The gold standard for directly measuring and assessing CRF is the cardiopulmonary exercise test (CPET), both in healthy and clinical populations [11]. However, even though in recent years the CPET has become a more feasible choice for CRF assessment, it is time-consuming, requires specialized and expensive laboratory facilities as well as expert personnel to supervise and is not widely available in many centers [12]. Therefore, the general population, and people with SZ in particular, rarely have the opportunity to perform this test, and as a result, CRF is the only major risk factor that is not regularly assessed in the clinical setting [13]. Thus, the recommendations suggest that when an exercise program is to be carried out, it should include the determination of CRF using at least predictive equations [11].

In this respect, when CPET is not feasible, CRF can be estimated using a variety of field tests by performing an exercise test with maximal effort to achieve high rates of perceived exertion and a percentage of an age-estimated maximum heart rate (HR) [14]. Accordingly, one of the most widely used field tests is the Modified Shuttle Walk Test (MSWT), which is considered suitable for all levels of function and allows a peak response to be elicited. Previous studies have assessed the association between the MSWT and $\mathrm{VO}_{2 \text { peak }}$ in different populations (i.e., adolescents, sedentary, lung cancer, chronic obstructive pulmonary disease, obese women, pulmonary arterial hypertension, and primary hypertension), concluding that this field walk test is objective, safe, valid, effective, reliable, and highly predictive for the assessment of functional capacity in each of the populations examined [15-24]. Nevertheless, like the rest of the tests, it may not be valid in all populations, and therefore, an analysis of the properties of the test (i.e., validity, reliability, repeatability, and sensitivity) should be carried out [25]. Originally, Singh et al. [26] proposed an equation to assess functional capacity in patients with chronic obstructive pulmonary disease using a 12-level protocol Incremental Shuttle Walk Test, the previous version of MSWT [19] and, more recently Jurio-Iriarte et al. developed another one for people with primary hypertension and obesity using the MSWT [27]. However, to the best of our knowledge, no reports are available that have analysed the relationship between the MSWT and $\mathrm{VO}_{2 \text { peak }}$ in a cohort of adults with SZ. Therefore, the aims of the present study were: (1) to validate the equation presented in the original study by Singh et al. for evaluating the relationship between MSWT with $\mathrm{VO}_{2 \text { peak }}$ in adults with SZ, (2) to develop a new equation for the MSWT to predict $\mathrm{VO}_{2 \text { peak, }}$ and (3) to validate the new equation.

\section{Materials and Methods}

\subsection{Study Participants}

The CORTEX-SP study was conducted between May 2018 and June 2021 in VitoriaGasteiz (Basque Country, Spain). This is a secondary baseline analysis of the study comprising a total of 144 participants (CORTEX) aged between 18 and 65 years ( $41.3 \pm 10.2$ years), 118 men $(81.9 \%)$, and 26 women (18.1\%). All participants had a diagnosis of SZ according to DSM-5 F20.9 (Diagnostic and Statistical Manual of Mental Disorders, Fifth Edition). All the selection criteria (exclusion and inclusion criteria) and procedures for the CORTEX-SP study have previously been described in the primary analysis [8]. The study was approved by the Research Ethics Committee of the Basque Country (PI2017044), and written informed consent was obtained from all participants before any data collection. 


\subsection{Measurements}

Body mass index (BMI) was calculated as the total body mass divided by height squared in meters $\left(\mathrm{kg} / \mathrm{m}^{2}\right)$. Waist and hip circumferences were taken, and the waist to hip ratio (WHR) was defined as waist circumference divided by hip circumference, both in centimeters. An ambulatory blood pressure (BP) monitoring recorder (ABPM) (6100 and 7100, Welch Allyn, New York, NY, USA) was used to measure BP for a whole day (24 h), through intervals of $30 \mathrm{~min}$ during the day and intervals of $60 \mathrm{~min}$ during the night. The variables considered from the ABPM measures were mean values of systolic BP, diastolic $\mathrm{BP}$, and $\mathrm{HR}$, all considered as resting values.

The CRF was assessed through a CPET and MSWT [28] on separate days. The CPET was performed on an electronically braked Lode Excalibur Sport Cycle Ergometer (Groningen, the Netherlands) starting at $40 \mathrm{~W}$ with a gradual increment of $10 \mathrm{~W}$ each minute in ramp protocol. The expired gas was analyzed with a system (Ergo CardMedi-soft S.S, Belgium Ref. USM001 V1.0) that was calibrated before each test in order to determine $\mathrm{VO}_{2 \text { peak, }}$ which was defined as the highest oxygen uptake value attained toward the end of the test. Achievement of $\mathrm{VO}_{2 \text { peak }}$ was assumed with the presence of two or more of the following criteria: (1) volitional fatigue ( $>18$ on Borg scale), (2) peak respiratory exchange ratio (RER) $\geq 1.1$, (3) achieving $>85 \%$ of age-predicted maximum heart rate, and (4) failure of oxygen consumption $\left(\mathrm{VO}_{2}\right)$ and/or HR to increase with further increases in work rate [29]. The MSWT consisted of walking/running up and down a $10 \mathrm{~m}$ corridor at an incremental speed, as previously described by Bradley et al. [28]. The test was finished when the participant (1) reached the end of level 15, (2) was too breathless to maintain the required speed, (3) was more than $0.5 \mathrm{~m}$ away from the cone when the beep sounded, (4) achieving $>85 \%$ of age-predicted maximum $\mathrm{HR}$, or (5) if the patient experienced chest pain or angina, dizziness, mental confusion, or extreme muscle fatigue $[28,30]$.

\subsection{Statistical Analysis}

Statistical analyses were performed using the $\mathrm{R}$ software package. Descriptive statistics were performed on the baseline participants' characteristics. The Ordinary Least Squares method was used to estimate the $\beta$ parameters of the equation from the sample data available. Subsequently, multiple linear regression was used to generalize a model, and we determined which variables were the strongest predictors of $\mathrm{VO}_{2 \text { peak }}$ through a variable selection algorithm. Forward stepwise linear regression was performed to test the effects of sex, age, body mass, BMI, WHR, systolic BP, diastolic BP, resting HR, peak $\mathrm{HR}$ at MSWT, and distance performed in the CPET, and to determine which variables are the strongest predictors of $\mathrm{VO}_{2 \text { peak }}$. In the residual analysis of the regression model, the type of method used for the assessment of outliers was Bonferroni test, for autocorrelation was Durbin-Watson test, and for homoscedasticity was Non-constant Variance Score test. Finally, for the validation of the model, we decided to use the k-fold cross-validation method $(\mathrm{k}=5)$. Statistical significance was set at $p<0.05$.

\section{Results}

Descriptive data from the sample are presented in Table 1, and descriptive results have already been presented [8].

The formula of Singh et al. [26] in the present cohort was calculated as:

$$
\mathrm{VO}_{2 \text { peak }}=[6.271+(0.021-\text { MSWT distance in meters })]
$$

The residuals showed poorly centered values by analyzing the median $(-0.811)$ and the minimum (-8.476) and maximum (15.071) ranges. Likewise, the predicted $\mathrm{VO}_{2 \text { peak }}$ was significant yet of moderate strength $\left(R^{2}=0.57\right)$, explaining $57 \%$ of the variance (adjusted $\mathrm{R}^{2}=0.57 ; p<0.001$ ) and indicating a standard error of the estimate (SEE) of $4.75 \mathrm{~mL} \cdot \mathrm{kg}^{-1} \cdot \mathrm{min}^{-1}$. In the residual analysis of the regression model, the tests applied for the assessment of outliers $(p=0.122)$ and autocorrelation $(p=0.712)$ returned insignificant 
$p$-values. However, the $p$-value obtained by the homoscedasticity values $(p=0.012)$ (i.e., constant variance) was significant.

Table 1. Characteristics of the studied population. Values are means \pm standard deviation or percentage (\%).

\begin{tabular}{|c|c|}
\hline Variables & $n=144$ \\
\hline Age (yrs) & $41.3 \pm 10.2$ \\
\hline Body mass (kg) & $83.6 \pm 16.4$ \\
\hline $\operatorname{BMI}\left(\mathrm{kg} / \mathrm{m}^{2}\right)$ & $28.7 \pm 7.4$ \\
\hline Waist (cm) & $96.6 \pm 14.1$ \\
\hline $\operatorname{Hip}(\mathrm{cm})$ & $104.3 \pm 9.5$ \\
\hline WHR & $0.93 \pm 0.09$ \\
\hline Resting systolic BP (mmHg) & $116 \pm 13$ \\
\hline Resting diastolic $\mathrm{BP}(\mathrm{mmHg})$ & $71 \pm 8$ \\
\hline Resting HR (bpm) & $81 \pm 11$ \\
\hline Cigarette smoking (\%) & 66 \\
\hline Diabetes Mellitus (\%) & 7.6 \\
\hline Antipsychotic treatment (\%) & 100 \\
\hline First-generation & 2.4 \\
\hline Second-generation & 93.6 \\
\hline Mixed & 4.0 \\
\hline \multicolumn{2}{|l|}{ CPET variables } \\
\hline Workload peak (W) & $126 \pm 37.7$ \\
\hline Distance (km) & $1.7 \pm 0.9$ \\
\hline HRpeak (bpm) & $152.3 \pm 19.7$ \\
\hline $\mathrm{VO}_{2 \text { peak }}\left(\mathrm{mL} \cdot \mathrm{kg}^{-1} \cdot \mathrm{min}^{-1}\right)$ & $23.3 \pm 7.2$ \\
\hline $\mathrm{RER}_{\text {peak }}$ & $1.2 \pm 0.1$ \\
\hline $\operatorname{MSWT}(\mathrm{m})$ & $798.9 \pm 265$ \\
\hline $\mathrm{HR}_{\text {peak }}$ in MSWT (bpm) & $153 \pm 22.4$ \\
\hline
\end{tabular}

BMI, body mass index; WHR, waist to hip ratio; BP, blood pressure; HR, heart rate; CPET: cardiopulmonary exercise test; $\mathrm{HR}_{\text {peak, }}$, peak heart rate; $\mathrm{VO}_{2 \text { peak }}$, peak oxygen uptake; $\mathrm{RER}_{\text {peak, }}$, peak respiratory exchange ratio; MSWT, modified shuttle walking test.

To potentially improve the prediction of $\mathrm{VO}_{2 \text { peak }}$, the present investigation used forward stepwise regression to identify other variables that may refine the prediction of $\mathrm{VO}_{2 \text { peak }}$. In such a procedure, variables were added sequentially to the regression model as long as they significantly improved the predictive power of the model. Only the variables that contribute to the estimates using backward stepwise approach were used in the model. In the residual analysis of the regression model, the tests applied for the assessment of outliers $(p=0.248)$ and autocorrelation $(p=0.868)$ returned insignificant $p$-values. However, the $p$-value obtained by the homoscedasticity values $(p=0.001)$, (i.e., constant variance) was significant. A logarithmic transformation was performed to try to correct the heteroscedasticity. After the logarithmic transformation, homoscedasticity hypothesis was finally satisfied $(p=0.828)$. In this case, the $\mathrm{VO}_{2 \text { peak }}$ was also significant, but still of moderate strength $\left(R^{2}=0.617\right)$, explaining, therefore, $60 \%$ of the variance (adjusted $\mathrm{R}^{2}=0.60 ; p<0.001$ ) and indicating a SEE of $4.55 \mathrm{~mL} \cdot \mathrm{kg}^{-1} \cdot \mathrm{min}^{-1}$ (Figure 1 ).

The equation generated in this study to calculate $\mathrm{VO}_{2 \text { peak }}\left(\mathrm{mL} \cdot \mathrm{kg}^{-1} \cdot \mathrm{min}^{-1}\right)$ from the MSWT can be formulated as follows:

$$
\mathrm{VO}_{2 \text { peak }}=20.168-[0.226 \cdot \mathrm{BMI}]-[0.064 \cdot \text { Resting HR }]+\left[0.019 \cdot \text { Distance }_{\mathrm{MSWT}}\right] \text {, }
$$

where BMI is expressed as $\mathrm{kg} / \mathrm{m}^{2}$, resting HR (beats per minute) is measured before starting the MSWT with at least 5 minutes of resting time, and distance is measured in meters travelled in the MSWT. 


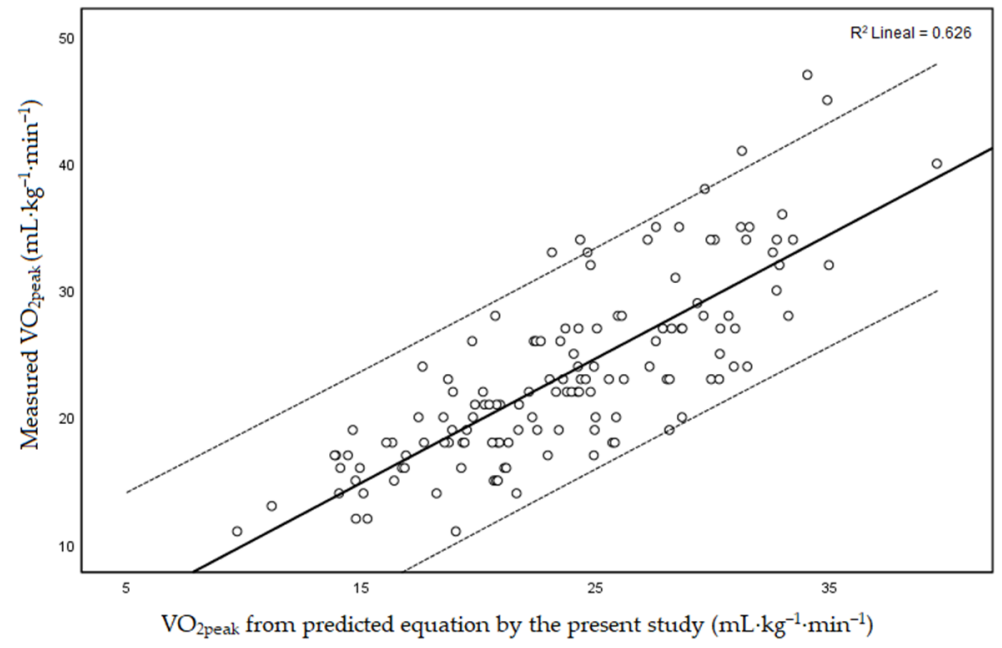

Figure 1. Relationship between measured $\mathrm{VO}_{2 \text { peak }}$ and $\mathrm{VO}_{2 \text { peak }}$ values from the predicted equation generated in the present study. The central line represents the linear regression line, and the flanking lines represent the $95 \%$ individual prediction intervals. CPET, cardiopulmonary exercise test; $\mathrm{VO}_{2 \text { peak }}$ peak oxygen uptake.

Figure 2 illustrates the proportional bias $(p<0.001)$ with limits of agreement from -8.9 to $8.2 \mathrm{~mL} \cdot \mathrm{kg}^{-1} \cdot \mathrm{min}^{-1}$. This indicates that using the new equation, the $\mathrm{VO}_{2 \text { peak }}$ assessment of $95 \%$ of participants with SZ would range from $8.9 \mathrm{~mL} \cdot \mathrm{kg}^{-1} \cdot \mathrm{min}^{-1}$ less to $8.2 \mathrm{~mL} \cdot \mathrm{kg}^{-1} \cdot \mathrm{min}^{-1}$ more than their objective measure by CPET. Bland-Altman plot (Figure 2) shows that the biggest and smallest individual means of $\mathrm{VO}_{2 \text { peak }}$ between the two tests correspond with the biggest limits of agreement on a proportional basis.

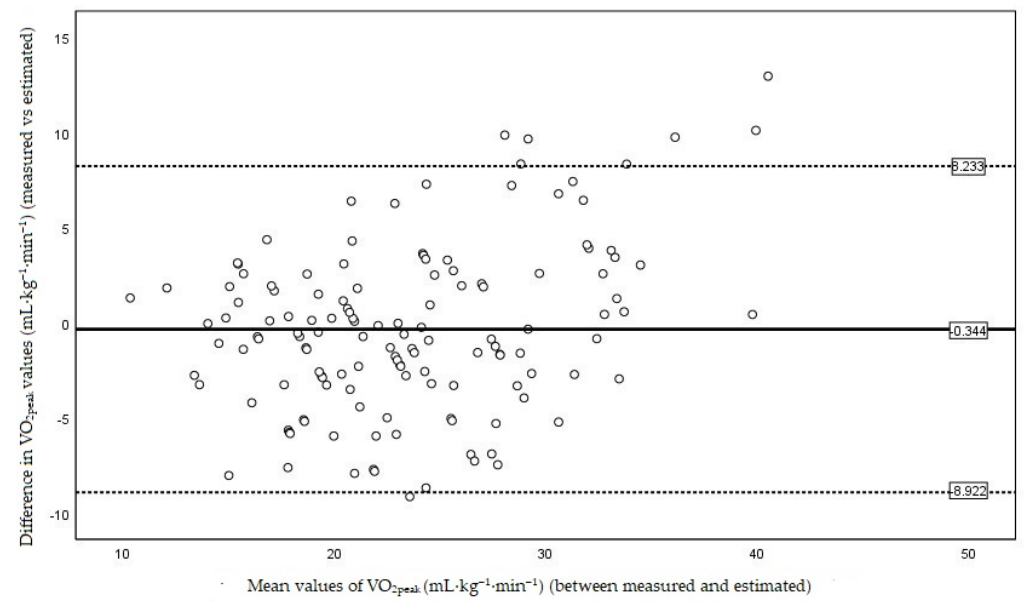

Figure 2. Bland and Altman plot. Intraindividual difference in $\mathrm{VO}_{2 \text { peak }}\left(\mathrm{mL} \cdot \mathrm{kg}^{-1} \cdot \mathrm{min}^{-1}\right)$ between two exercise tests (MSWT vs. CPET) plotted against intraindividual mean values of the exercise tests (MSWT and CPET). The central line represents the mean of the intraindividual differences, and the flanking lines represent the $95 \%$ limits of agreement.

For the agreement and validity of the new equation, the summary of sample sizes created the five subsets (Table 2) and indicated the sample size of each of them $(109,109$, $110,108,108$ ). The $\mathrm{R}^{2}$ was 0.626 (Figure 1 ), compared with that of the original model, which was 0.617 . Hence, it can be indicated that they are very similar and that the model is robust. Likewise, the average standard deviation of the subsets $(\mathrm{SD}=0.092)$ was low, indicating a low variability between the models created. In summary, after the cross-validation method, it was concluded that the model was stable. 
Table 2. The evaluation indices for the 5-fold cross-validation.

\begin{tabular}{cccc}
\hline Subsets & RMSE & $\mathbf{R}^{\mathbf{2}}$ & MAE \\
\hline 1 & 4.617 & 0.668 & 3.302 \\
2 & 4.292 & 0.681 & 3.307 \\
3 & 4.862 & 0.557 & 3.757 \\
4 & 4.196 & 0.636 & 3.155 \\
5 & 4.617 & 0.586 & 3.906 \\
\hline
\end{tabular}

RMSE, Root mean square error; MAE, mean absolute error.

\section{Discussion}

In the present study, an analysis of the relationship between the MSWT and $\mathrm{VO}_{2 \text { peak }}$ in a cohort of the SZ population was carried out. The main findings of this study were: (1) a new equation incorporating BMI, resting HR, and distance from MSWT performed better than the original Singh et al. equation [26] to estimate $\mathrm{VO}_{2 \text { peak }}$ for the studied population, and (2) the posteriori cross-validation method confirmed the model's stability.

Previous studies have also presented correlations between measures of the shuttle walk test and CPET, explaining the $40.6 \%$ (healthy men) [16] and $57 \%$ (general surgical patients) [31] of the variance in $\mathrm{VO}_{2 \text { peak }}$ and showing viability for the prediction of $\mathrm{VO}_{2 \text { peak }}$. However, according to the present results, these equations, and even the equation of Singh et al. [26], may not be an appropriate method to estimate CRF through the MSWT for the assessment of functional capacity in people with SZ. Thus, the estimation equation by Singh et al. [26] showed that the residual values were poorly centered and only explained $57 \%$ of the variance (adjusted $R^{2}=0.57$ ). The lack of precision could be because Singh et al. [26] generated the equation for patients with chronic airway obstruction, whose main limitation to exercise is dyspnea. In contrast to pulmonary patients, the performance of people with SZ is not usually limited by breathlessness but by exhaustion, low CRF, side effects relating to treatment (antipsychotic drugs), anhedonia, and lack of motivation [8,32]. Hence, among the variables obtained in the proposed models, BMI, and resting HR, together with the distance walked in the MSWT, proved to be the most relevant predictors. These variables explained the $60 \%$ of the variation in $\mathrm{VO}_{2 \text { peak }}$ for the new equation, increasing the $\mathrm{R}^{2}$ and decreasing the SEE compared to Singh et al. equation (Figure 1). According to that, for the sample studied, the higher the BMI and resting HR, and the lower the distance walked at MSWT, the poorer the CRF. This can be explained by the inverse associations of high BMI, including an excess visceral adipose tissue (i.e., systemic inflammation) and elevated resting HR (i.e., increased sympathetic activity) with low CRF [33,34]. As an example of using the newly generated equation could be the following: if we provide two actual values observed for two participants with opposite CRF values included in this sample (Participant 1: measured $\mathrm{VO}_{2 \text { peak }}=40 \mathrm{~mL} \cdot \mathrm{kg}^{-1} \cdot \mathrm{min}^{-1} ; \mathrm{BMI}=21.3 \mathrm{~kg} / \mathrm{m}^{2}$; distance at $\mathrm{MSWT}=1500 \mathrm{~m}$; resting $\mathrm{HR}=67 \mathrm{bpm}$. Participant 2: measured $\mathrm{VO}_{2 \text { peak }}=$ $11 \mathrm{~mL} \cdot \mathrm{kg}^{-1} \cdot \mathrm{min}^{-1} ; \mathrm{BMI}=46.6 \mathrm{~kg} / \mathrm{m}^{2}$; distance at MSWT $=330 \mathrm{~m}$; resting $\mathrm{HR}=97 \mathrm{bpm}$ ), the estimated $\mathrm{VO}_{2 \text { peak }}$ values would be 39.6 and $9.7 \mathrm{~mL} \cdot \mathrm{kg}^{-1} \cdot \mathrm{min}^{-1}$, respectively, which corresponds with a very low error of estimate $\left(0.4\right.$ and $1.3 \mathrm{~mL} \cdot \mathrm{kg}^{-1} \cdot \mathrm{min}^{-1}$, respectively).

One of the scientific goals of the present study was to predict an outcome (i.e., the $\left.\mathrm{VO}_{2 \text { peak }}\right)$. Therefore, the metric by which to assess the quality of the prediction should be decided [35]. Previous studies have not validated the original formula $[18,26]$ or there was a medium-validation result [27] without full support of the equation validity. In the current study, after using the cross-validation method, it was concluded that the model was stable with an $R^{2}=0.626$ and had a high similarity with the newly generated equation $\left(R^{2}=0.617\right)$. Thus, the present results support the validity of the equation for routinely determining the CRF of SZ patients using the MSWT and the generated equation. However, we must be cautious with this statement since the validity of the MSWT-estimated $\mathrm{VO}_{2 \text { peak }}$ is still moderate (60\% of the variance). In this sense, in the clinical setting, when an accurate determination of CRF is critical, the CPET (with objective $\mathrm{VO}_{2 \text { peak }}$ assessment) will remain the "gold standard". 
The current study has several strengths. Considering the difficulties involved in recruiting volunteers with a mental dysfunction, we could argue a relatively large sample $(n=144)$. Furthermore, the new equation could be a very useful and easy tool in the evaluation of this population, and the results obtained with this prediction are better compared to previous studies. There are, however, some limitations of this study that should be considered: (1) Symptoms affect each individual differently and have a direct bearing when assessing stress testing. (2) Cycle ergometer and MSWT tests are performed on different days and the motivation for exercise is highly variable from day-to-day in this population. (3) It has been observed that $\mathrm{VO}_{2 \text { peak }}$ tends to be somewhat higher in those tests performed on a treadmill compared to those on a bike ergometer. Therefore, the SEE of the new equation $\left(4.55 \mathrm{~mL} \cdot \mathrm{kg}^{-1} \cdot \mathrm{min}^{-1}\right)$ could be increased, since the direct measurement of $\mathrm{VO}_{2 \text { peak }}$ has been done on the bike while the MSWT test is performed walking [36]. (4) The average age of the current cohort was $41.3 \pm 10.2$ years (range 18-65 years). This could limit the accuracy of the equation in younger or older individuals. (5) The ethnicity in the present study was predominantly white non-Hispanic ( $99 \%)$, suggesting that there may be potential ethnicity-related differences in the accuracy of the equation.

Finally, these results provide evidence for an easy, fast, and simple way to evaluate the CRF of people with SZ when objective measurements are not available. This would allow the necessary pre-design assessment of exercise in both clinical and non-clinical settings, and the promotion of exercise programs in this population.

\section{Conclusions}

In summary, the findings of this study support the validity of a new regression equation incorporating resting $\mathrm{HR}, \mathrm{BMI}$, and distance from MSWT to predict $\mathrm{VO}_{2 \text { peak }}$ for assessment of CRF in people with SZ. However, when an accurate determination of functional capacity is required for diagnosis, clinical research, and exercise design, the direct measurement of $\mathrm{VO}_{2 \text { peak }}$ will continue to be the "gold standard".

Author Contributions: Conceptualization, M.T.-E. and S.M.-M.; methodology, E.E., P.M.S., and S.M.M.; formal analysis, M.T.-E.; investigation, M.T.-E., N.I.-Y., E.E., P.M.S., A.S., and S.M.-M.; resources, N.I.-Y., E.E., P.M.S., and S.M.-M.; data curation, M.T.-E. and A.S.; writing—original draft preparation, M.T.-E. and S.M.-M.; writing-review and editing, M.T.-E., S.R.d.A., P.M.S., A.S., and S.M.-M.; visualization, M.T.-E. and S.M.-M.; supervision, E.E., P.M.S., and S.M.-M.; project administration, N.I.-Y., E.E., P.M.S., and S.M.-M.; funding acquisition, S.R.d.A., E.E., P.M.S., and S.M.-M. All authors have read and agreed to the published version of the manuscript.

Funding: This study was supported by the Spanish Ministry of Economy and Competitiveness "Fondo de Investigación Sanitaria del Instituto de Salud Carlos III" (PI16/01022) and the Department of Education and Science of the Basque Government (Team A) (IT946-16). MTE was supported by the University of the Basque Country (UPV/EHU) with a predoctoral grant. AS was supported by a Fellowship from the Fundación Tatiana Pérez de Guzmán el Bueno. This study is registered at 11 April 2018 in www.clinicaltrials.gov (NCT03509597).

Institutional Review Board Statement: The study was conducted according to the guidelines of the Declaration of Helsinki and approved by the Ethics Committee of the Basque Country (PI2017044).

Informed Consent Statement: Informed consent was obtained from all subjects involved in the study.

Acknowledgments: Our special thanks to Amaia Ortiz de Zarate for all the support in the recruitment and management of patients. Also, thanks to the Council of Vitoria-Gasteiz for the facilities in the Research Center for Physical Activity and Health. Last but not least, thanks to all the participants for their willingness, which made this project possible, all the undergraduate and postgraduate students who collaborated in this project, IBJ7 for your daily support, and especially to Borja Jurio-Iriarte for providing his previous research as a model for this article; we send him all our strength and best wishes for a speedy recovery.

Conflicts of Interest: The authors declare no conflict of interest. 


\section{References}

1. Stubbs, B.; Firth, J.; Berry, A.; Schuch, F.B.; Rosenbaum, S.; Gaughran, F.; Veronesse, N.; Williams, J.; Craig, T.; Yung, A.R.; et al. How Much Physical Activity do People with Schizophrenia Engage in? A Systematic Review, Comparative Meta-Analysis and Meta-Regression. Schizophr. Res. 2016, 176, 431-440. [CrossRef] [PubMed]

2. Ratliff, J.C.; Palmese, L.B.; Reutenauer, E.L.; Liskov, E.; Grilo, C.M.; Tek, C. The Effect of Dietary and Physical Activity Pattern on Metabolic Profile in Individuals with Schizophrenia: A Cross-Sectional Study. Compr. Psychiatry 2012, 53, 1028-1033. [CrossRef] [PubMed]

3. Mukundan, A.; Faulkner, G.; Cohn, T.; Remington, G. Antipsychotic Switching for People with Schizophrenia Who have Neuroleptic-Induced Weight Or Metabolic Problems. Cochrane Database Syst. Rev. 2010, 12. [CrossRef]

4. Correll, C.U.; Robinson, D.G.; Schooler, N.R.; Brunette, M.F.; Mueser, K.T.; Rosenheck, R.A.; Marcy, P.; Addington, J.; Estroff, S.E.; Robinson, J.; et al. Cardiometabolic Risk in Patients with First-Episode Schizophrenia Spectrum Disorders: Baseline Results from the RAISE-ETP Study. JAMA Psychiatry 2014, 71, 1350-1363. [CrossRef] [PubMed]

5. De Hert, M.; Dekker, J.M.; Wood, D.; Kahl, K.G.; Holt, R.I.; Moller, H.J. Cardiovascular Disease and Diabetes in People with Severe Mental Illness Position Statement from the European Psychiatric Association (EPA), Supported by the European Association for the Study of Diabetes (EASD) and the European Society of Cardiology (ESC). Eur. Psychiatry 2009, 24, 412-424. [CrossRef]

6. Saiz Ruiz, J.; Bobes Garcia, J.; Vallejo Ruiloba, J.; Giner Ubago, J.; Garcia-Portilla Gonzalez, M.P.; Grupo de Trabajo sobre la Salud Fisica del Paciente con Esquizofrenia. Consensus on Physical Health of Patients with Schizophrenia from the Spanish Societies of Psychiatry and Biological Psychiatry. Actas Esp. Psiquiatr. 2008, 36, 251-264. [PubMed]

7. American Diabetes Association; American Psychiatric Association; American Association of Clinical Endocrinologists; North American Association for the Study of Obesity. Consensus Development Conference on Antipsychotic Drugs and Obesity and Diabetes. Diabetes Care 2004, 27, 596-601. [CrossRef] [PubMed]

8. Tous-Espelosin, M.; de Azua, S.R.; Iriarte-Yoller, N.; MartinezAguirre-Betolaza, A.; Sanchez, P.M.; Corres, P.; Arratibel-Imaz, I.; Sampedro, A.; Pena, J.; Maldonado-Martin, S. Clinical, Physical, Physiological, and Cardiovascular Risk Patterns of Adults with Schizophrenia: CORTEX-SP Study: Characterization of Adults with Schizophrenia. Psychiatry Res. 2021, 295, 113580. [CrossRef]

9. Despres, J.P. Physical Activity, Sedentary Behaviours, and Cardiovascular Health: When Will Cardiorespiratory Fitness Become a Vital Sign? Can. J. Cardiol. 2016, 32, 505-513. [CrossRef]

10. Kaminsky, L.A.; Arena, R.; Ellingsen, O.; Harber, M.P.; Myers, J.; Ozemek, C.; Ross, R. Cardiorespiratory Fitness and Cardiovascular Disease-The Past, Present, and Future. Prog. Cardiovasc. Dis. 2019, 62, 86-93. [CrossRef] [PubMed]

11. Ross, R.; Blair, S.N.; Arena, R.; Church, T.S.; Despres, J.P.; Franklin, B.A.; Haskell, W.L.; Kaminsky, L.A.; Levine, B.D.; Lavie, C.J.; et al. Importance of Assessing Cardiorespiratory Fitness in Clinical Practice: A Case for Fitness as a Clinical Vital Sign: A Scientific Statement from the American Heart Association. Circulation 2016, 134, e653-e699. [CrossRef]

12. Kokkinos, P.; Kaminsky, L.A.; Arena, R.; Zhang, J.; Myers, J. New Generalized Equation for Predicting Maximal Oxygen Uptake (from the Fitness Registry and the Importance of Exercise National Database). Am. J. Cardiol. 2017, 120, 688-692. [CrossRef] [PubMed]

13. Peterman, J.E.; Whaley, M.H.; Harber, M.P.; Fleenor, B.S.; Imboden, M.T.; Myers, J.; Arena, R.; Kaminsky, L.A. Comparison of Non-Exercise Cardiorespiratory Fitness Prediction Equations in Apparently Healthy Adults. Eur. J. Prev. Cardiol. 2021, 28, 142-148. [CrossRef]

14. Kaminsky, L.A.; Myers, J.; Arena, R. Determining Cardiorespiratory Fitness with Precision: Compendium of Findings from the FRIEND Registry. Prog. Cardiovasc. Dis. 2019, 62, 76-82. [CrossRef] [PubMed]

15. Gomes, A.L.; Mendonca, V.A.; Dos Santos Silva, T.; Pires, C.K.V.; Lima, L.P.; Gomes, A.M.; Camargos, A.C.R.; Neves, C.D.C.; Lacerda, A.C.R.; Leite, H.R. Cardiorespiratory and Metabolic Responses and Reference Equation Validation to Predict Peak Oxygen Uptake for the Incremental Shuttle Waking Test in Adolescent Boys. PLoS ONE 2018, 13, e0206867. [CrossRef]

16. Neves, C.D.; Lacerda, A.C.; Lage, V.K.; Lima, L.P.; Fonseca, S.F.; de Avelar, N.C.; Teixeira, M.M.; Mendonca, V.A. Cardiorespiratory Responses and Prediction of Peak Oxygen Uptake during the Shuttle Walking Test in Healthy Sedentary Adult Men. PLoS ONE 2015, 10, e0117563. [CrossRef]

17. Granger, C.L.; Denehy, L.; Parry, S.M.; Martin, J.; Dimitriadis, T.; Sorohan, M.; Irving, L. Which Field Walking Test should be used to Assess Functional Exercise Capacity in Lung Cancer? An Observational Study. BMC Pulm. Med. 2015, 15, 89. [CrossRef]

18. Win, T.; Jackson, A.; Groves, A.M.; Sharples, L.D.; Charman, S.C.; Laroche, C.M. Comparison of Shuttle Walk with Measured Peak Oxygen Consumption in Patients with Operable Lung Cancer. Thorax 2006, 61, 57-60. [CrossRef] [PubMed]

19. Campo, L.A.; Chilingaryan, G.; Berg, K.; Paradis, B.; Mazer, B. Validity and Reliability of the Modified Shuttle Walk Test in Patients with Chronic Obstructive Pulmonary Disease. Arch. Phys. Med. Rehabil. 2006, 87, 918-922. [CrossRef] [PubMed]

20. Turner, S.E.; Eastwood, P.R.; Cecins, N.M.; Hillman, D.R.; Jenkins, S.C. Physiologic Responses to Incremental and Self-Paced Exercise in COPD: A Comparison of Three Tests. Chest 2004, 126, 766-773. [CrossRef]

21. Jurgensen, S.P.; Trimer, R.; Dourado, V.Z.; Di Thommazo-Luporini, L.; Bonjorno-Junior, J.C.; Oliveira, C.R.; Arena, R.; Mendes, R.G.; Borghi-Silva, A. Shuttle Walking Test in Obese Women: Test-Retest Reliability and Concurrent Validity with Peak Oxygen Uptake. Clin. Physiol. Funct. Imaging 2015, 35, 120-126. [CrossRef]

22. Jurgensen, S.P.; Trimer, R.; Di Thommazo-Luporini, L.; Dourado, V.Z.; Bonjorno-Junior, J.C.; Oliveira, C.R.; Arena, R.; Borghi-Silva, A. Does the Incremental Shuttle Walk Test Require Maximal Effort in Young Obese Women? Braz. J. Med. Biol. Res. 2016, 49. [CrossRef] [PubMed] 
23. Mainguy, V.; Malenfant, S.; Neyron, A.S.; Saey, D.; Maltais, F.; Bonnet, S.; Provencher, S. Alternatives to the Six-Minute Walk Test in Pulmonary Arterial Hypertension. PLoS ONE 2014, 9, e103626.

24. Jurio-Iriarte, B.; Gorostegi-Anduaga, I.; Aispuru, R.; Perez-Asenjo, J.; Brubaker, P.; Maldonado-Martin, S. Association between Modified Shuttle Walk Test and Cardiorespiratory Fitness in Overweight/Obese Adults with Primary Hypertension: EXERDIETHTA Study. J. Am. Soc. Hypertens. 2017, 4, 186-195. [CrossRef]

25. Bradley, J.; Howard, J.; Wallace, E.; Elborn, S. Reliability, Repeatability, and Sensitivity of the Modified Shuttle Test in Adult Cystic Fibrosis. Chest 2000, 117, 1666-1671. [CrossRef] [PubMed]

26. Singh, S.J.; Morgan, M.D.; Scott, S.; Walters, D.; Hardman, A.E. Development of a Shuttle Walking Test of Disability in Patients with Chronic Airways Obstruction. Thorax 1992, 47, 1019-1024. [CrossRef] [PubMed]

27. Jurio-Iriarte, B.; Brubaker, P.H.; Gorostegi-Anduaga, I.; Corres, P.; Martinez Aguirre-Betolaza, A.; Maldonado-Martin, S. Validity of the Modified Shuttle Walk Test to Assess Cardiorespiratory Fitness After Exercise Intervention in Overweight/Obese Adults with Primary Hypertension. Clin. Exp. Hypertens. 2019, 41, 336-341. [CrossRef]

28. Bradley, J.; Howard, J.; Wallace, E.; Elborn, S. Validity of a Modified Shuttle Test in Adult Cystic Fibrosis. Thorax 1999, 54, 437-439. [CrossRef]

29. Mezzani, A.; Hamm, L.F.; Jones, A.M.; McBride, P.E.; Moholdt, T.; Stone, J.A.; Urhausen, A.; Williams, M.A.; European Association for Cardiovascular Prevention and Rehabilitation; American Association of Cardiovascular and Pulmonary Rehabilitation; et al. Aerobic Exercise Intensity Assessment and Prescription in Cardiac Rehabilitation: A Joint Position Statement of the European Association for Cardiovascular Prevention and Rehabilitation, the American Association of Cardiovascular and Pulmonary Rehabilitation, and the Canadian Association of Cardiac Rehabilitation. J. Cardiopulm. Rehabil. Prev. 2012, 32, 327-350. [PubMed]

30. Hanson, L.C.; Taylor, N.F.; McBurney, H. The 10m Incremental Shuttle Walk Test is a Highly Reliable Field Exercise Test for Patients Referred to Cardiac Rehabilitation: A Retest Reliability Study. Physiotherapy 2016, 102, 243-248. [CrossRef]

31. Struthers, R.; Erasmus, P.; Holmes, K.; Warman, P.; Collingwood, A.; Sneyd, J.R. Assessing Fitness for Surgery: A Comparison of Questionnaire, Incremental Shuttle Walk, and Cardiopulmonary Exercise Testing in General Surgical Patients. Br. J. Anaesth. 2008, 101, 774-780. [CrossRef] [PubMed]

32. Rastad, C.; Martin, C.; Asenlof, P. Barriers, Benefits, and Strategies for Physical Activity in Patients with Schizophrenia. Phys. Ther. 2014, 94, 1467-1479. [CrossRef] [PubMed]

33. Arsenault, B.J.; Lachance, D.; Lemieux, I.; Almeras, N.; Tremblay, A.; Bouchard, C.; Perusse, L.; Despres, J.P. Visceral Adipose Tissue Accumulation, Cardiorespiratory Fitness, and Features of the Metabolic Syndrome. Arch. Intern. Med. 2007, 167, 1518-1525. [CrossRef] [PubMed]

34. Kang, S.J.; Ha, G.C.; Ko, K.J. Association between Resting Heart Rate, Metabolic Syndrome and Cardiorespiratory Fitness in Korean Male Adults. J. Exerc. Sci. Fit. 2017, 15, 27-31. [CrossRef] [PubMed]

35. Benkeser, D.; Petersen, M.; van der Laan, M.J. Improved Small-Sample Estimation of Nonlinear Cross-Validated Prediction Metrics. J. Am. Stat. Assoc. 2020, 115, 1917-1932. [CrossRef]

36. Turley, K.R.; Wilmore, J.H. Cardiovascular Responses to Treadmill and Cycle Ergometer Exercise in Children and Adults. J. Appl. Physiol. 1997, 83, 948-957. [CrossRef] 